\title{
ALUMINUM CASTING LABORATORY IMPLEMENTATION TO BUILD COMPETENCE OF TEACHER CANDIDATE OF VOCATIONAL HIGH SCHOOL
}

\author{
Arianto Leman Soemowidadgo ${ }^{1}$, Widarto ${ }^{1}$, Tiwan ${ }^{1}$, Aan Ardian ${ }^{1,}$ Silvia Sianipar ${ }^{2}$ \\ ${ }^{1}$ Department of Mechanical Engineering Education, Faculty of Engineering, Universitas Negeri Yogyakarta \\ ${ }^{2}$ Manufacturing Engineering Study Program, Faculty of Engineering, Universitas Negeri Yogyakarta \\ Email: arianto_ls@uny.ac.id
}

\begin{abstract}
This study aimed at implementing Casting Laboratory model to build competence of teacher candidate of Vocational High School of Mechanical Engineering Study Program. The study is conducted by try out application approach. The procedure comprised of equipment preparation, layout arrangement, practice and evaluation. Data were collected by observation. The research subject was two classes of third semester bachelor students of MEED YSU who enrolled in Advanced Engineering Materials practical course. The two classes consist of 4 teams and within each team there were 4 groups. The practical work was carried out 2 times. The results show that the Casting Laboratory model has met all of the qualification of a learning facility to build student competence in unpressurized casting process. Among these competencies are ability in pattern making, sand preparation, sand-mold making, planning raw materials and smelting process, handling and pouring of molten metal, disassembling and cleaning, and evaluating the cast. The Casting Laboratory layout has qualified as work area for casting practice. The layout makes supervision and movement of workers and materials easy. Tools and equipment are fitting and adequate. The Laboratory model for aluminum casting is effective and efficient to develop competence in casting.
\end{abstract}

Keywords: implementation, casting laboratory, teacher candidate, casting competence

\begin{abstract}
ABSTRAK
Penelitian ini bertujuan menerapkan model Laboratorium Pengecoran untuk membentuk kompetensi calon guru Sekolah Menengah Kejuruan Program Studi Teknik Mesin. Penelitian dilakukan dengan pendekatan uji aplikasi. Prosedur terdiri dari persiapan peralatan, pengaturan tata letak, praktik dan evaluasi. Data dikumpulkan dengan observasi. Subjek penelitian adalah adalah 2 kelas mahasiswa semester tiga program S1 teknik mesin MEED YSU yang mengikuti praktik bahan teknik lanjut, terdiri dari 4 tim dan masing-masing tim dibagi menjadi 4 kelompok. Praktikum dilaksanakan dua kali. Hasil penelitian menunjukkan bahwa model Laboratorium Pengecoran telah memenuhi syarat sebagai fasilitas pembelajaran untuk membentuk kompetensi siswa dalam proses pengecoran tanpa tekanan. Kompetensi yang dibentuk adalah kemampuan dalam membuat pola, menyiapkan pasir, membuat cetakan pasir, merencanakan bahan baku dan proses melebur, menanganani dan menuangkan logam cair, membongkar dan membersihkan, serta mengevaluasi produk pengecoran. Tata letak Laboratorium Pengecoran telah memenuhi syarat sebagai area kerja untuk praktik pengecoran. Ini memberi kemudahan dalam pengawasan dan pergerakan orang dan barang. Alat dan peralatan sudah sesuai dan memadai. Model laboratorium untuk pengecoran aluminium efektif dan efisien untuk mengembangkan kompetensi pengecoran.
\end{abstract}

Kata kunci: penerapan, laboratorium pengecoran, calon guru, kompetensi pengecoran

\section{INTRODUCTION}

Unskilled worker is a problem of majority ASEAN member countries (Grosch, 2017: 281). In Indonesia, this condition related to the Vocational High School (VHS) as the skilled worker provider institution. Many limitations inhibit the VHS in providing skilled worker required. Availability of learning facilities and appropriate competence of teacher as a driver of learning dynamic in VHS is still become an issue that continuously develop. The instruction of President of the Republic of Indonesia number 9 date $9^{\text {th }}$ September 2016 
proclaimed VHS revitalization to promote skilled worker providing. This should be responded immediately through the learning facilities development and the teacher competence improvement as required.

Technical and Vocational Education and Training (TVET) institution that provides VHS teachers, directly connected with this issue in providing skilled worker produced by VHS. Learning programs in VHS should be dynamically comply with science and technology progress as well as worker skill requirements (Istanto, 2016: 149). The consequence is that TVET should pursue the dynamic development of VHS. Teachers are the main factor in achieving learning goals (Dwi, 2015: 271). Therefore, TVET should continuously transform in learning media, models, methods, systems, programs and facilities and also laboratories (Tiwan, et.al, 2017: 218). Mechanical Engineering Education Department of Yogyakarta State University (MEED YSU) as one of the TVET, also has responsibility in developing VHS teachers of Mechanical Engineering Program. This related to the fact that the teacher has main role in learning process in developing students' competence. The teacher existence is very crucial and unchangeable by other factors (Istanto, 2016: 144).

Casting is one of the basic process in product making that should be possessed by graduate of VHS. It is written in the Decree of Director General of Middle Education of Indonesian Education and Culture Ministry number 06/D.D5/KK/2018 declared at 7th June 2018. The implication is that a teacher of Mechanical Engineering Vocational Program should have competence in casting process both theoretically and practically. However, almost all VHS in Indonesia that conduct mechanical engineering program only gives theory of casting process without any practice. This represents the lack of teacher's competence in casting process or insufficiency of casting practice facilities.
Furnace is the main facility in casting process to melt a metal. Aluminum can be melted using a crucible furnace. This furnace is simple and widely used in small and middle industries, home industry and also education field. Charcoal, oil or gas can be used as energy source of crucible furnace. (Ighodalo, et.al, 2011: 448-450; Aditya Nag \& Dareddy, 2012: 474-477; Olalere, et.al, 2015: 281-288; Suresh \& Nagarjun, 2016: 1-5). An innovation of crucible furnace with an economizer has been developed as the facility in casting process at MEED YSU. (Arianto, et.al, 2017: 21-27). A spiral finned crucible pot has also been developed as further innovation to improve the efficiency of crucible furnace with an economizer. (Arianto, et.al, 2018: 1-6).

Casting practice has been developed in several VHS around Yogyakarta (Arianto, et.al, 2014: 80-94) and Magelang (Arianto, et.al, 2017: 277-284). The equipment for sand mold making, foundry and casting, disassembly and cleaning of casting products has also been created. Furthermore, A prototype of mini compact crucible furnace has been developed (Arianto, et.al, 2019: 45-53; Arianto, et.al, 2020: 1-8) with purpose to obtain appropriate furnace for casting practice.

However, MEED YSU have no certain area to build casting competence of the teacher candidate, whereas the competence developed are only sand mold making; melting and pouring; disassembly and cleaning; and casting product analysis. They do not have competence in pattern design, pattern making, casting design, and gating system design. It is obviously important to develop a casting laboratory at MEED YSU in order to build competence capacity in casting. TVET as an institution which prepare ready-to-use teacher candidate is demanded to improve the education quality in order to face the technology challenge and employment opportunity (Riana, 2016: 111).

Tiwan, et al. (2017: 218-222) had been developed casting laboratory model especially for aluminum at MEED YSU that comprises 
layout design and equipment of pattern making, core making, sand mold making, disassembly and cleaning casting product, health and safety work, and also materials for foundry and mold. The application of the previously developed aluminum casting laboratory will be evaluated. This is important to assure that aluminum casting laboratory could support the competence of MEED YSU students as they are the teachers' candidate of Mechanical Engineering VHS Program.

\section{METHOD}

This survey research is conducted by observing the learning of aluminum casting practice. This is done at the aluminum casting laboratory model at MEED YSU which is integrated with material and processing laboratory. The research subject was the third semester students of S1 program of mechanical engineering of MEED YSU that taken advance engineering material practice. They are two classes which consist of 4 teams and each team divided into 4 groups. The research target is to realize aluminum casting laboratory that feasible for perform the aluminum casting practice. The research is done by application trial of aluminum casting laboratory model. This aimed at knowing the performance of aluminum casting laboratory model in aspects of economic, efficiency, and effectivity. The economic aspect is reviewing the cost that required for operating aluminum casting practice. The efficiency aspect is reviewing the laboratory area needed, time needed to learn casting competence and the equipment use. Whilst, the effectivity aspect is reviewing suitability of laboratory as a place to build the casting competence.

The steps of application trial procedure are preparing the styrofoam and wood pattern; setting up the crucible furnace with economizer, gas burner and its tools; preparing $20 \mathrm{~kg}$ of aluminum raw material; providing the pattern, flasks, and green sand; mold making; melting the aluminum raw material; pouring; disassembly and cleaning castings product; observing and checking casting product. Observation was done during the research to evaluate the implementation aluminum casting practice.

The data related to the preparing, process and result of aluminum casting process were collected by observing and documenting. Then they were presented in statements, tables and figures. They were analyzed descriptively by explaining facts that occurred during practice activity.

\section{RESULT AND DISCUSSION}

The casting laboratory is integrated with material and processing laboratory. It has an area of $14 \times 6 \mathrm{~m} 2$. This space has only one side wall and roofed with suspended awning to protect from the sun exposure. By this concept, although this casting laboratory build in limited area but the casting practice could be conduct, since there is no wall on the three other sides so it has wide open space. This concept is developed also with consideration of safety and healthy work. The space of casting laboratory is divided into 8 work areas (Tiwan, 2017: 219). First area is for cleaning and observing the casting product. In this area the casting product is cleaned from sand that still left on the surface after disassembled from sand mold. Gating system that comprises of pouring basin, sprue, runner, riser and gate are removed by cutting process. Visual observation is then conducted to determine the defect that could appear. The second is the sand casting area, where the sand is prepared before making the sand mold. The sand mold is made and disassembled in this area. Appropriate placement must be conducted in order to attain proper area utilization. The concept has been made to obtain efficient and effective area usage. There is a wide compartment containing sand. It is only around $50 \mathrm{~cm}$ in height and equipped with lid to keep the sand when it is not used. The third area is for processing the sand. In this area the sand is processed to make it ready for sand mold making. The sand is processed by mixing it with 
a binder such as bentonite or clay and water. The sand that has been used for casting will be reprocessed. Pattern is made in fourth area. Wood, polystyrene or epoxy resin can be used to make a pattern. Aluminum as raw material is melted in fifth area. The crucible furnace and tools for pouring process is laid in this area. The furnace is placed in an appropriate location to give optimum safety and easy to access in order to maintain melting and pouring process done safely. A good process of melting and pouring is needed to obtain a good product. The sixth area is the storage area, where materials for casting process such as aluminum as raw material, material for pattern and core making and also other material are stored. Those materials are put in cabinets, compartment and storage racks. Tools and equipment for casting practice are saved in cabinets, compartment and storage racks in the seventh area. These tools and equipment are grouped according to the types, easiness to pick up and storage, and also frequency of use. The eighth area is for sand testing. The quality warranty of casting product will be obtained by maintaining the sand quality. For this purposes the sand for casting should be tested. The testing comprises water content, sand strength, sand grain distribution and permeability.

The aluminum casting laboratory is designed as practice facility for undergraduate students and to build the skill in casting and mold making especially competence unit of LOG.0004.002.01. Based on the decree of Indonesian Labor and Transmigration Ministry number KEP. 240/MEN/X/2004 about National Work Standard Competence in metal and machine sector, this unit competence build a skill in pressureless casting. The competence built comprises preparing and making mold, manual pouring, taking the casting product, cleaning mold and working area, and implementing safety on work.

Casting practice is conducted by steps of pattern making in $2 \times 50$ minutes; sand mold making, melting, pouring and product cleaning in $2 \times 100$ minutes; observing and investigating casting product in 2 x 50 minutes. Maximum number of student in each practice session is 40 person which divided into 8 groups with maximum 5 person per group. The practice job comprises all of competence that should be possessed in making a simple product from pattern making until investigating product.

The students design the product that will be made. The product must be made from aluminum which the dimension is limited by flask dimension of $300 \mathrm{~mm}$ x $300 \mathrm{~mm}$ x $70 \mathrm{~mm}$. After deciding what product that will be made, the students discuss how to make it. They have to discuss in their group about the casting process design which start from the shape and dimension of the pattern before expressed in technical drawing. The next step is designing sand mold making and the gating system. Each group presents the discussion result and discuss it with other groups in the whole class. There are two kinds of pattern should be made, one is made from styrofoam and the other is from wood.

The purpose of the pattern making process is to develop the students' competence in preparing pattern for casting. The competence that is built in pattern making comprises reading the technical drawing, producing the technical drawing, using the hand tool for styrofoam pattern making, using the hand tool for wood pattern making and understanding the pattern requirements for sand mold making. Based on the observation during practice, the students possess the ability in making simple pattern for casting process. Investigation of pattern made by students shows several drawbacks such as lack of side inclination, sharp angle edge pattern, less smooth surface, and different thickness at different location. Figure 1 shows examples of wood pattern that made by student.

Creativity and innovation are important in pattern making process. Experience after many time practicing will develop the students' skill well. This will lead the student as the teacher candidate have a good skill in developing product both for education purposes and for sale to public. Thus, it will build the student 
capability to be a teacher-preneur that able to change the challenge and problems in education into a profitable opportunity (Endang, 2015: 63). Mastery in technology could build entrepreneur perception significantly (M. Yahya, 2016: 39). Based on those two statements, creativity and innovation in the casting process not only build the student competence but also build competence in entrepreneurship. It is important for a teacher to build their self-confidence.
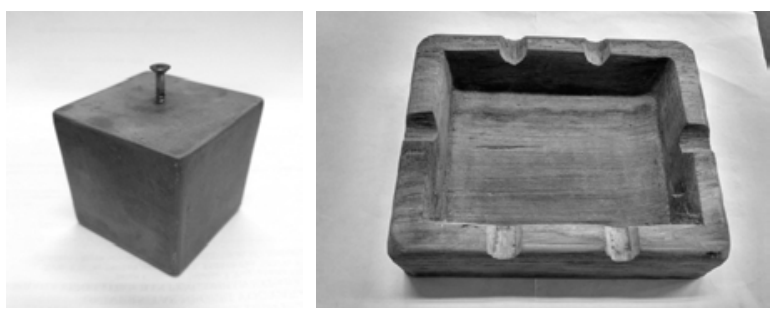

Figure 1. Wood pattern made by student

After finishing the pattern, the sand mold is made. This step is to develop the student competence in preparing sand for casting, placing pattern in the coupe and drag properly, putting in and compacting sand in the flasks, and gating system making. In preparing the sand, student practices how to control the composition of water so the student gets precise feeling for the sand wetness. Figure 2 shows the students practicing in making sand mold. Students are able to make sand mold using pattern from styrofoam and wood. Each group requires 10-25 minutes to prepare the sand by adding water in appropriate amount and mixing homogeneously. In mold making process with styrofoam pattern, each group requires 20-30 minutes, whilst using wood pattern, each group requires 20-100 minutes. The wide range of time required using wood pattern is caused by the pattern design, complexity and surface smoothness. Pattern with less side inclination and less smooth surface is difficult to lift up from the sand. Pattern with complex shape also gives more complexity in sand mold making. On the contrary, due to the the styrofoam pattern do not need to be lifted up from the sand, time range it requires is narrower. However, the gating system in casting using styrofoam pattern should be considered carefully. Otherwise, defects on the casting product will appear due to the trapped sublimate stryofoam when the molten aluminum is poured.

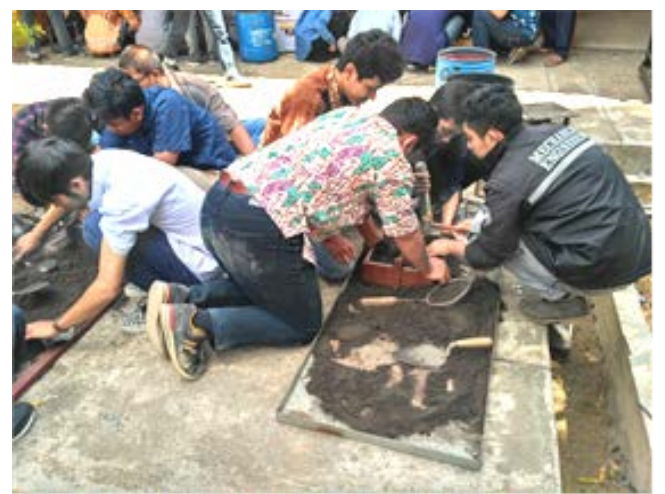

Figure 2. Students practicing making sand mold

Aluminum smelting process was conducted when students making the sand mold. In smelting process, students preparing aluminum raw material, furnace, and other equipments. The smelting process is done in a crucible furnace that equipped with economizer using spiral finned pot (Arianto, et.al, 2017: 16). The competence that build in this step are ability in preparing raw material, operating the crucible furnace, put in the material to be smelted, and also predict and measure pouring temperature. The smelting process was conducted in such way so that the aluminum melted when process of mold making is finish. This is for efficiency of the practice time. The aluminum requirement for practice of 8 groups is $12-15 \mathrm{~kg}$ and it took around 30 minutes for smelting process and requires $3 \mathrm{~kg}$ of Liquid Petroleum Gas (LPG).

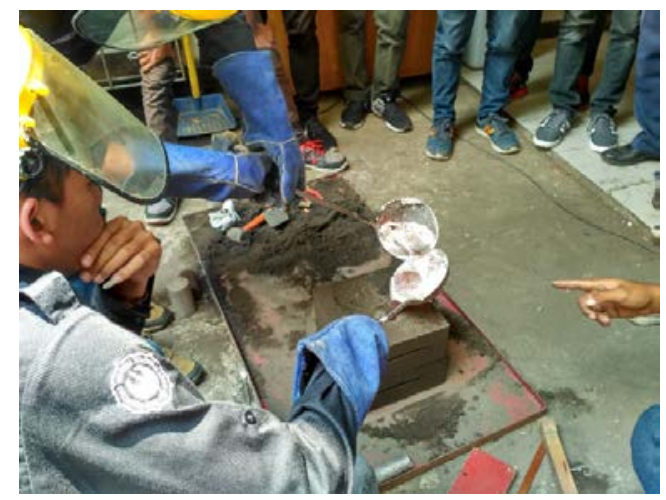

Figure 3. Students poured molten aluminum into the sand mold 
Pouring process is conducted when the sand mold is ready and the molten aluminum has reach proper temperature. Figure 3 shows students pouring the molten aluminum into the sand mold cavity. The student competence that build in this step is ability in handling the molten metal. Students are able taken out the crucible from furnace, bring, and pour into the sand mold. Time necessity for taking out the crucible from furnace is $0,5-1$ minutes and it takes $1-2$ minutes to carry to the mold. The pouring process into the mold also takes 1-2 minutes. The time requires to do those process is depend on the product dimension and the distance of the furnace to the mold. Process of pouring molten metal and filling mold cavity is a critical step in metal casting. The behavior of molten metal and solidifying process determining the perfection of casting product and prevent from defects (Reddy \& Rajanna, 2009: 1).

The sand mold disassembled after the molten metal solidify and then the casting product is taken. Disassembly process is conducted 5 minutes after solidifying. Disassembly is done by breaking the sand mold using trowel. After disassembled process, the casting product is cleaned from sand which sticked and the gating system trimmed. Final product is obtained by grinding and honing. It has been observed that students had have possess good competence in cleaning the casting product. The students already have basic competence in sawing, honing, and grinding from bench work lesson. Student requires 5-15 minutes to clean the casting product depend on to complexity of the product. Figure 4 shows the casting product that made in the casting practice. Based on Figure 4, student learn the product differences that made using styrofoam and wood pattern. Stryofoam pattern, produce gas from sublimated stryofoam which causes defect on product. However, the stryofoam pattern is easier in making the sand mold. Advantages and disadvantages of this two kind pattern, make students could understanding casting process better. It is clear that the student as mechanical engineering candidate teacher has possess competence in making a product from aluminum by casting process. Student could give appreciation to the product through values of work, working consciousness, elegance, cleanliness, quality so it have high sale value (M. Yahya, 2016: 31).

The last step of the casting practice is investigating and analyzing the product. In their group, the student discussing, observing, making note, draw, and describe defects that appear on casting product and then analyzing the cause of those defect. This activity is shown in Figure 5. At this stage, students have been able to describe dan analize the defects that occur in the castings. Defects encountered in the casting product are imperfect shape, holes in the surface, sand inclusions, sand fall out and rough surfaces.

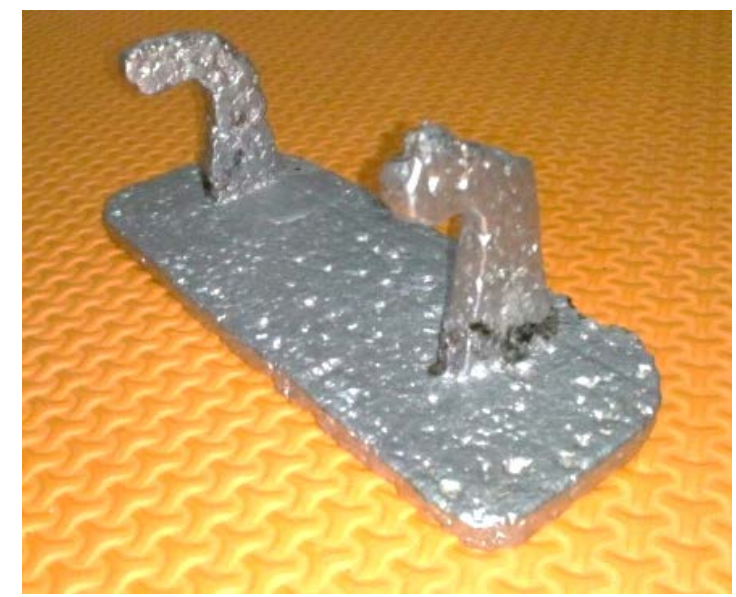

(a)

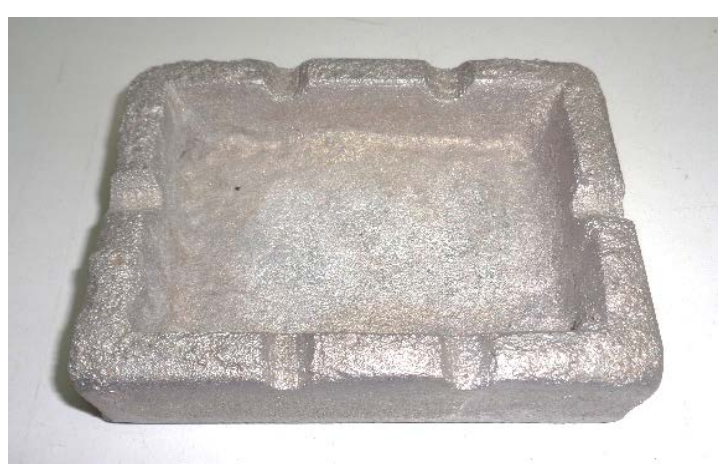

(b)

Figure 4. The casting product made by: (a) styrofoam pattern; (b) wood pattern. 


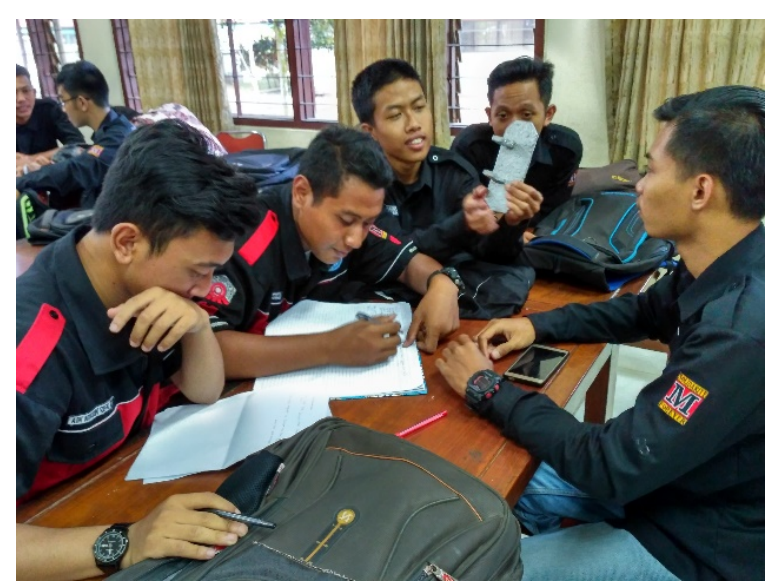

Figure 5. Discussion to analyze casting product

Each group has finish practicing the casting process and obtain a product that correspond with the pattern. However, there are two groups that failed making product using styrofoam pattern. One group is inappropriate in making the gating system and causing the molten metal cannot fill the mold cavity well. The unsuccessful of the other group is caused by improper in predicting the amount of poured molten metal so the mold cavity not full filled. On casting using wood pattern, each group obtain casting product that consistent with pattern. The competencies possessed by student in pressureless casting after casting practice is shown in Table 1. It is obvious that the casting laboratory of MEED YSU is effective in building the casting competence. The practice activities in build casting competencies are appropriate to contextual learning. Contextual learning is a learning concept that can help student in connecting learning material and real situation. The contextual experience will improving student ability in mastering the learning material. (Suroso, et.al, 2015: 180). This is also consistent with Riana (2016: 119) who stated that student ability in understanding practice learning is better with contextual learning.

Cost to conduct the casting practice for 8 groups is IDR 848.000 as shown in Table 2. Thus, cost of casting practice for each group is IDR 106.000. This cost is for aluminum raw material, LPG and other consumable materials. Cost to conduct this casting practice is cheap and affordable. This will be more economical if the product from casting practice can be sold or used as blank on machining practice. The casting laboratory model is adequate as workshop for practice learning in build competence in casting field. Layout arrangement, tools and equipment, learning media, competence ofinstructor and technician is sufficient. Facilities and infrastructure such as electricity, water, and work bench equipment are also available.

Table 1. Competence obtained in casting practice of JPTM MEED YSU

\begin{tabular}{|c|c|c|}
\hline \multirow{2}{*}{ Competence } & \multicolumn{2}{|c|}{ Learning experience } \\
\hline & Obtained & Not obtained \\
\hline Able to design and making pattern from styrofoam and wood & $\checkmark$ & \\
\hline Able to preparing sand for mold & $\checkmark$ & \\
\hline Able to make sand molding & $\checkmark$ & \\
\hline Able to conduct smelting process & $\checkmark$ & \\
\hline Able to manage molten metal & $\checkmark$ & \\
\hline Able to poure molten metal into sand mold & $\checkmark$ & \\
\hline Able to disassembling and cleaning the casting product & $\checkmark$ & \\
\hline Able to examine and evaluating the casting product & $\checkmark$ & \\
\hline
\end{tabular}


Table 2. Consumable cost for casting practice

\begin{tabular}{lcr}
\hline \multicolumn{1}{c}{ Consumable } & Amount & Cost (IDR) \\
\hline Aluminium raw materials & $15 \mathrm{~kg}$ & 450.000 \\
Liquid Petroleum Gas & $3 \mathrm{~kg}$ & 36.000 \\
Bentonite & $50 \mathrm{~kg}(1 \mathrm{sack})$ & 185.000 \\
Graphite powder & $50 \mathrm{~kg}(1 \mathrm{sack})$ & 69.000 \\
Leaf saw & 4 piece & 52.000 \\
Grinding stone 3,5 inchi & 4 piece & 54.000 \\
\hline \multicolumn{2}{c}{ Total cost } & 848.000 \\
\hline
\end{tabular}

Laboratory layout has ful fill the ergonomic requirements as work place for casting practice. The work area provide safety since equipped with safety equipment and comfortable for students in 8 groups to do casting practice. Equipment or machinery arrangement is based on work flow or the work type. It is laid out by type, size, and uniformity of equipment. Integrated area in one location gives easiness in movement, interaction between students and instructor, and simplify supervision. The casting laboratory is a semi open space, thus utilizes natural lighting optimally to save energy and easily to access by light truck. The location of the laboratory is flood-free and safe from fire potential. Tool and equipment is match with the work demands in casting job which consists of equipment for smelting, casting, sand mold processing, mold making, disassembling and cleaning of castings. There also available sufficient equipment for health and work safety. All equipment is available in sufficient quantities for 8 groups. All of those equipment meets the requirements and functioned properly.

The casting practice has provide complete learning experience in building competence in casting and mold making. The steps of the casting process has programmed, coherent and well implemented thus from preparation to inspection could be well understood by the students. This is shown by the student ability in conducting casting practice and on the good casting product. The casting laboratory model at MEED YSU is effective and efficient to develop student competence in casting field since the practice process is match with the learning goal. All of the competence that match with competence unit of LOG.0O04.002.01. have been done during casting practice process.

\section{CONCLUSION}

The aluminum casting laboratory developed has qualified as practice learning facility to build competence in casting process and mold making in pressurless casting. The built competencies comprises of the ability in pattern making, preparation of green sand, sand mold making, planning raw material and smelting process, molten metal handling and pouring, disassembling and cleaning of casting product and evaluating the casting product. The students are able make pattern from stryofoam and wood and they also able make a sand mold from stryofoam and wood pattern. The laboraotium layout meets the requirements of ergonomics as a workshop for practicing the casting process. Tools and equipment are suitable with the demands of work for casting practice process. The health and safety equipment is available and sufficient.

\section{REFERENCES}

Aditya Nag, M. V., \& Dareddy, R. D. 2012. Performance Improvement Of An Oil Fired Furnace Through Oscillating Combustion Technology. International Journal of Scientific \& Engineering Research, 3(7), 474-477.

Arianto. L.S, Tiwan, \& Mujiyono. 2014. Development of Aluminum Melting Furnace for Developing Casting Competence at VHS of Mechanical 
Engineering Program, Inotek, 18(1), 8094.

Arianto L.S., Tiwan, \& Mujiyono. 2017. Tungku Krusibel dengan Economizer untuk Praktik Pengecoran di Jurusan Pendidikan Teknik Mesin FT UNY. Jurnal Dinamika Vokasional Teknik Mesin, 2(1), 21-27.

Arianto L.S., Tiwan, Sutopo, \& Nurdjito. 2017. Aluminum Casting Facilities for VHS of Mechanical Engineering Program, National Conference Proceeding of Vocational Education 2017, 277-284, Faculty of Engineering. YSU.

Arianto L.S., Tiwan, Widarto, \& Aan A. 2018. Spiral Finned Crucible Pot. The $3^{\text {rd }}$ International Conference on Industrial, Mechanical, Electrical, and Chemical Engineering. Surakarta. AIP Conference Proceedings 1931, 030066, (doi.org/10.1063/1.5024125) 1-6.

Arianto L.S., F.A. Ristadi., Adiaksa G., Bima Y., \& Galang D.Z. 2019. Prototipe Tungku Krusibel Kompak Mini, Jurnal Dinamika Vokasional Teknik Mesin, 4(1), 45-53.

Arianto, L.S., FA Ristadi, \& Aan A. 2020. Performance Test of Prototype of Mini Compact Crucible Furnace, Journal of Physics: Conference Series 1446012002 , doi:10.1088/1742-6596/1446/1/012002, 1-8.

Director General of Middle Education Decree number 06/D.D5/KK/2018 about spectrum expertise of Middle Vocational Education.

Dwi J., 2015. Effect of Teaching Performance, Parents Involvement, Self Actualization against Achievement Motivation. Jurnal Pendidikan dan Teknologi Kejuruan, 22(3), 262-273.

Endang Mulyatiningsih. 2015. Analysis of Strengths and Weaknesses to be Teacherpreneurs in Vocational School. Jurnal Kependidikan, 45(1), 62-75.
Grosch, M. 2017. Developing A Competency Standard For TVET Teacher Education 2In ASEAN Countries. Jurnal Pendidikan dan Teknologi Kejuruan, 23(3), 279-287.

Ighodalo, O. A., Akue, G., Enaboifo, E., \& Oyedoh, J. 2011.. Performance Evaluation of the Local Charcoal-Fired Furnace for Recycling Aluminium. Journal of Emerging Trends in Engineering and Applied Sciences (JETEAS), 2(3), 448450.

Instruction of President of Indonesian Republic number 9. 2016. Vocational High School revitalization.

Istanto Wahyu Djatmiko. 2016. A Study on The Empowering Teachers' Professional Development And Quality Assurance to Increase Teachers' Effectiveness in Vocational Secondary Schools. Jurnal Pendidikan dan Teknologi Kejuruan, 23(2), 144-151.

M. Yahya. 2016. The Effect of Work-Based Learning on Entrepreneurial Insights. Jurnal Kependidikan. 46(1), 29-40.

Olalere1, A. A., Dahunsi, O. A., Akintunde, M. A., \& Tanimola, M. O., (2015). Development Of A Crucible Furnace Fired With Spent Engine Oil Using Locally Sourced Materials. International Journal of Innovation and Applied Studies, 13(2), 281-288.

Riana T. Mangesa. 2016. The Implementation of Contextual Approach in Electrical Installation Learning Process. Jurnal Kependidikan, 46(1), 110-120.

Reddy, A. C. \& Rajanna, C. 2009. Design of gravity die casting process parameters of Al-Si-Mg Alloys. Journal of Machining and Forming Technologies, 1(1/2), 141165.

Suroso M.L, A. Syachruroji, \& Pipit M. 2015. Development of Biology Conservation Teaching Materials Based on 
Ethnopedagogy. Jurnal Kependidikan, 45(2), 168-183.

Suresh. R., \& Nagarjun, M. G., (2016). Construction and Performance analysis of Pit furnace by using Biodiesel. Indian Journal of Science and Technology, 9(45), 1-5.
Tiwan, Arianto L.S., Widarto, and Aan A. 2017. Aluminum Casting Laboratory to Develop Competencies of Vocational High School Teacher Candidate Proceeding $1^{\text {st }}$ International Conference on Technology and Vocational Teachers. vol. 102 (Yogyakarta: Faculty of Engineering/Yogyakarta State University/ Atlantis Press/ doi.org/10.2991/ictvt17.2017.37), 218-222 